\title{
Nitrogen and phosphorus transport as a criterion for soil categorisation
}

\author{
Stanislav Torma ${ }^{1}$, Štefan Koco ${ }^{1,2 *}$, Jozef Vilček ${ }^{1,2}$ \\ ${ }^{1}$ National Agricultural and Food Centre, Soil Science and Conservation Research Institute, regional work place Prešov, Raymannova 1, 08001 \\ Prešov, Slovak Republic \\ ${ }^{2}$ University of Prešov, Faculty of Humanities and Natural Sciences, Department of Geography and Regional Development, $17^{\text {th }}$ November Str. 15 , \\ 08001 Prešov, Slovak Republic \\ * Dr. Štefan Koco, e-mail: stefan.koco@nppc.sk, ORCID iD: https://orcid.org/0000-0003-4352-0295
}

Received: February 3, 2020

Accepted: May 25, 2020

Associated editor: A. Horel

\section{Keywords}

Soil transport function

Soil categorization

Nitrogen

Phosphorus

Water pollution

\begin{abstract}
Water pollution, both surface and underground, by agricultural activity is a relatively serious problem. The pollutants are transported from the soil to the water. The aim of this paper is to evaluate the soil transport function on the basis of present knowledge of soil nutrient (nitrogen and phosphorus) transport and soil and local properties. The west Slovak lowlands, south Slovak basins and east Slovak highlands were selected due to their different climate and soil parameters. Soil nutrient transport was classified as (1) very weak, (2) weak, (3) moderate, (4) strong and (5) very strong. Accordingly, we defined the area of individual categories of soil transport function in agricultural soils in three observed areas in Slovakia. Thus we could determine the origin of the water pollution potential risk. Moreover, this is very important when it comes to observing of the Nitrate Directive as farmers can harmonise nitrogen and phosphorus fertilisation to soil categories. In the case of nitrogen, its transport is very dependent on soil nitrification intensity with nitrogen, and the most fertile soils (on Žitný ostrov) are very susceptible to water pollution. Almost $88 \%$ of agricultural soil in this area are in the strong and very strong nitrogen transport categories. On the other hand, only $2.1 \%$ of soils in hilly and cold landscapes (Ondavská vrchovina) feature water nitrogen pollution. Phosphorus transport is very strong on the hilly landscape with shallow soils (less than $0.30 \mathrm{~m}$ ) and/or with gravel high content (Ondavská vrchovina). Especially in these locations, an increase of water body phosphorus content and thus a decrease in water quality (almost $50 \%$ of total agricultural soil area) is possible.
\end{abstract}

\section{Introduction}

Surface and groundwater nitrate $\left(\mathrm{NO}_{3}^{-}\right)$pollution is considered one of the most important water quality issues worldwide (Nolan, 2001; Puckett et al., 2011). Since the end of the 1950s, $\mathrm{NO}_{3}^{-}$ concentrations in surface water and in groundwater are continuously increasing (Billen and Garnier, 1999; Birgand et al., 2007). An increase of $\mathrm{NO}_{3}^{-}$concentration in surface water can trigger primary production and therefore anoxic conditions, promoting the eutrophication of water bodies (Rivett et al., 2008).

Agricultural activity can pollute both surface and groundwater sources. Water pollution may result from improper agricultural practice, especially due to the incorrect application of chemical substances (fertilisers, pesticides, etc.) (Mind'aš and Škvarenina, 1995; Behera et al., 2003; Zhu et al., 2005; Garnier et al., 2010; Torma et al., 2013, Koco et al., 2016, Fazekašová et al., 2016) and the properties of the soil itself may also be a factor. Organic and inorganic pollutants can enter into the soil either by incorrect application of selected materials or by some kind of "error" (ecological accident, insufficient filtering of waste, etc.). However, nutrients are deliberately supplied to the soil in order to increase its fertility resulting in crop yield increase. In this paper, we focus on the problem of possible water pollution with nitrogen and phosphorus because these two nutrients are the main causes of change in water quality and eutrophication. Transport of potassium (as third basic nutrient in agriculture) is more of an economic than an environmental problem we will not be discussing further in this research.

Pollution of water resources (surface and underground) by agricultural activity is a relatively serious problem (Horel et al., 2014; Torma and Vilček, 2015). Water pollution caused by agricultural practices means that the above mentioned nutrients are transported from the soil to the water. We assumed that the nutrients not accumulated in the soil or consumed by the plants are transported, with varying intensity, into water sources depending on soil properties and site characteristics. The transport mechanism can be categorized i) vertically (through the in-depth soil profile) or ii) horizontally (on the soil surface). Re-

(C) 2020 by the authors. Licensee Soil Science Society of Poland. This article is an open access article distributed under the terms and conditions of the Creative Commons 174 Attribution (CC BY NC ND 4.0) license (https://creativecommons.org/licenses/by-nc-nd/4.0/). 
gardless of which mechanism is implemented, in most cases the destination of the pollutants is water. Soil transport property is one of its main ecological functions, playing a dominant role in water pollution. Meanwhile, agriculture is considered one of the main sources of nitrogen pollution, inter alia, through nitrate leaching to the groundwater (Oenema et al., 2011; Gömöryová et al., 2013). Furthermore, the application of nitrogen fertilisers increases the danger of water source pollution (Goulding, 2000; Di and Cameron, 2002; Zhang et al. 2005; Engström et al. 2010, Tang et al., 2010). Nitrate leaching to groundwater alone represents a loss of soil fertility and also a threat to the environment and human health (Addiscott, 1996; Timsina et al., 2001; Di and Cameron, 2002; Ju et al., 2009; Hou et al., 2012; Shen et al., 2013; Sui et al., 2015).

The aim of this paper is to compare three Slovak regions (lowlands, basins and highlands) characterized by different soil and climate parameters in terms of possible water pollution originating from the soil.

The maps of potential water sources pollution were created using an algorithm based on soil and local parameters.

\section{Materials and methods}

Our research is focused on three Slovakian regions to demonstrate the differences in nutrient transport intensities and also possible water resource pollution (Fig. 1).

The studies presented in this work were carried out in three different regions of Slovakia (Džatko, 2002). Žitný ostrov in Western Slovakia (132,807 ha of agricultural soils) represents the lowlands with an altitude from 105 to $143 \mathrm{~m}$ a.s.l. (mean altitude $117 \mathrm{~m}$ a.s.l.). The most widespread soil types in this region are Chernozems and Fluvisols. South Slovakian basins in the middle of Slovakia (122,132 ha of agricultural soils), which include Ipel'ská kotlina, Lučenecká kotlina and Rimavská kotlina represent the typical basins, and their altitudes vary from 125 to $409 \mathrm{~m}$ a.s.l. (mean altitude $218 \mathrm{~m}$ a.s.l.). The Dystric Planosols and Haplic Luvisols are the most widespread soil types in this region. Ondavská vrchovina in the eastern part of Slovakia (136,514 ha of agricultural soils) represents the highlands with altitude from 119 to $870 \mathrm{~m}$ a.s.l. (mean altitude $347 \mathrm{~m}$ a.s.l.). The dominant soil types in this region are Cambisols and Gleyic Fluvisols. The characteristics of all three regions are presented in Table 1.

The basis for this paper was to check the possibility of nutrient (nitrogen and phosphorus) transport from the soil in two directions, e.g. leaching into the depths outside the soil profile and water erosion nutrient overland flow. For this type of research, the decisive factors were the atmospheric conditions (especially the amount of precipitation) and terrain slope.

In the case of nitrogen transport, the problem is mainly related to nitrate anion leaching. $\mathrm{NO}_{3}^{-}$is highly soluble in soil water, is poorly adsorbed by soil particles and is therefore prone to be leached by the water percolating along the soil profile. We assumed that the more nitrates undergoing nitrification in the soil, the more nitrates should be leached.

The amount of nitrified nitrogen in the soil was defined by Bielek (1998). Accordingly, the amount of nitrified nitrogen in the soil is described thus:

$y=0.33 \cdot e^{0.0151 x}$

where:

$\mathrm{y}-$ the mean intensity of pure nitrification $\left(\mathrm{mg} \mathrm{N}-\mathrm{NO}_{3}{ }^{-} \mathrm{kg}\right.$ soil per 14 days);

$\mathrm{x}$ - soil quality score (from 100-point scale).

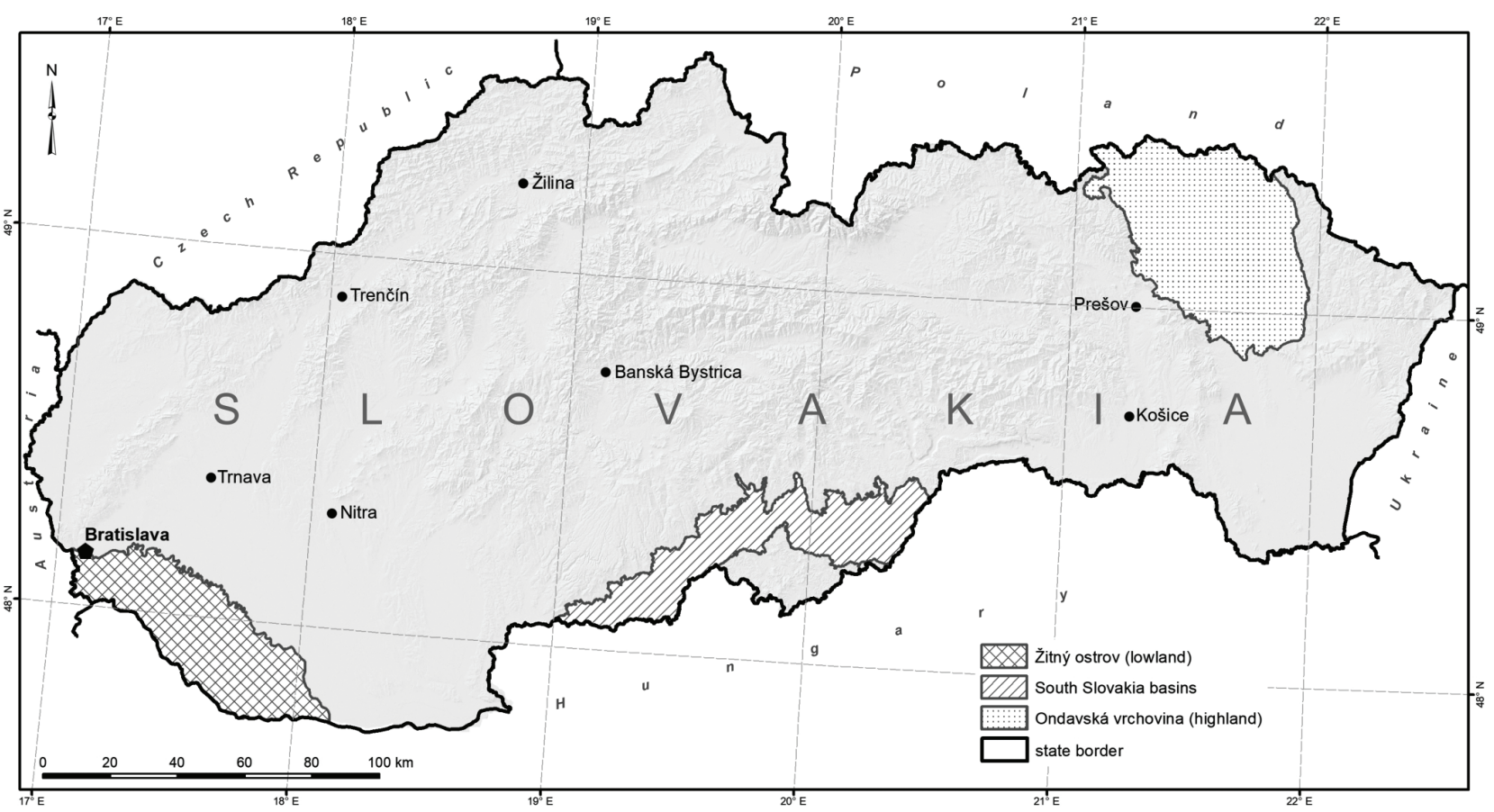

Fig. 1. The study area for evaluation of soil nitrogen and phosphorus transport (Žitný ostrov, South Slovakian basins and Ondavská vrchovina) 
Table 1

The chosen characteristics of the observed regions

\begin{tabular}{lll}
\hline Parameter / region & Žitný ostrov & South Slovakian basins \\
\hline Altitude (m a.s.l.) & $105-140$ & $125-409$ \\
\hline Mean annual temperature $\left({ }^{\circ} \mathrm{C}\right)(1961-1990)$ & $9->10$ & $6-10$ \\
\hline Mean annual precipitation (mm) (1961-1990) & $<500-600$ & $550-700$ \\
\hline Most widespread soil types & $\begin{array}{l}\text { Chernozems, } \\
\text { Eutric Fluvisols, Mollic Fluvisols }\end{array}$ & $\begin{array}{l}\text { Haplic Luvisols, Dystric } \\
\text { Planosols, Gleyic Fluvisols }\end{array}$ \\
\hline Mean soil quality score (from 100-point scale) & 85.7 & $600-1000$ \\
\hline
\end{tabular}

According to Bielek (1998), all soils in Slovakia were divided into up to 11 representative groups for which the amount of nitrified nitrogen was determined within the growing season (245 days). The smallest amount of nitrogen (less than $20 \mathrm{~kg}$ $\mathrm{N}^{-\mathrm{NO}_{3}}{ }^{-}$) is nitrified in Podzol, Solonchak and Solonetz (point value 3-10). On the other hand, the largest amount of nitrogen (more than $75 \mathrm{~kg} \mathrm{~N}-\mathrm{NO}_{3}^{-}$) is nitrified in Calcaric Haplic Chernozems and Mollic Fluvisols (point value 60-100) (Džatko, 2002).

Field location plays an important role in water erosion. The steeper the terrain slope, the more soil (including nitrogen attached to soil particles) can be transported by water erosion. Therefore, slope size is an important parameter also taken into the account in nitrogen transportation on the soil surface. The coefficients for the slope category are presented in Table 2.

There were five categories of the soil nitrogen transportation capacity created by a mutual combination of both above mentioned factors (amount of soil nitrified nitrogen and slope coefficients).

The phosphorus transport in the soil depends on "soil volume", i.e. it is dependent on the soil depth, particle size distribution and, naturally, on terrain slope. The amount of transported phosphorus is proportional to both terrain slope and soil texture but is inversely proportional to soil depth. This means that less phosphorus should be transported from greater soil depths and vice versa, the higher the gravel content and the steeper the slope, the more phosphorus should be transported from the soil. Categorisation of soil phosphorous transportation capacity is based on a combination of above mentioned soil and location parameters. All necessary soil parameters can be taken from the database of the Soil Monitoring System of Slovak soils. Detailed analyses of parameters and assignment of coefficients was published by Torma (2003).

The coefficients for mentioned soil and location parameters are presented in Table 2 . We obtained 60 parameter combinations on the basis of three soil depth, four soil gravel content and five location slope categories.

Spatial identification and quantification of soils were performed according to above mentioned parameters on the basis of the soil parameter data layer in the observed regions using a geographic information system, i.e. the ArcGIS environment (Fig. 2).

For the purpose of this paper, the maps of nutrient transport within the soil (potential water source pollution) for the three observed regions were created by ArcGIS 10.3 software on the basis of the above mentioned method.

\section{Results and discussion}

Water-body contamination occurs when there is a high nitrogen and phosphorus content near the soils (Carpenter et al., 1988; Kumazawa, 2002; Ju et al., 2005). This is caused by imbalance between the applied nutrients in agriculture in the form of mineral fertiliser or manure and crop nutrients uptake (Mekonnen et al., 2016). Although nitrogen losses through leaching vary over a field due to diversification of the soil physical properties and $\mathrm{N}$ status of soil (Xu et al., 2013), just the wrong application of fertilisers (disproportionately high doses, application at the wrong time, etc.) is one of the most common rea-

Table 2

Soil and locality parameters and assigned coefficients for transport calculation

\begin{tabular}{|c|c|c|c|c|c|}
\hline \multicolumn{6}{|l|}{ Parameters } \\
\hline Soil depth (m) & $0.0-0.3$ & $0.3-0.6$ & $>0.6$ & & \\
\hline Coefficient & 0.8 & 0.5 & 0.2 & & \\
\hline Gravel contents $(\%)$ & $0-5$ & $5-25$ & $25-50$ & $>50$ & \\
\hline Coefficient & 0.4 & 0.6 & 0.8 & 1.0 & \\
\hline Locality slope $\left(^{\circ}\right)$ & $0-3$ & $3-7$ & $7-12$ & $12-17$ & $>17$ \\
\hline Coefficient & 0.2 & 0.4 & 0.6 & 0.8 & 1.0 \\
\hline
\end{tabular}




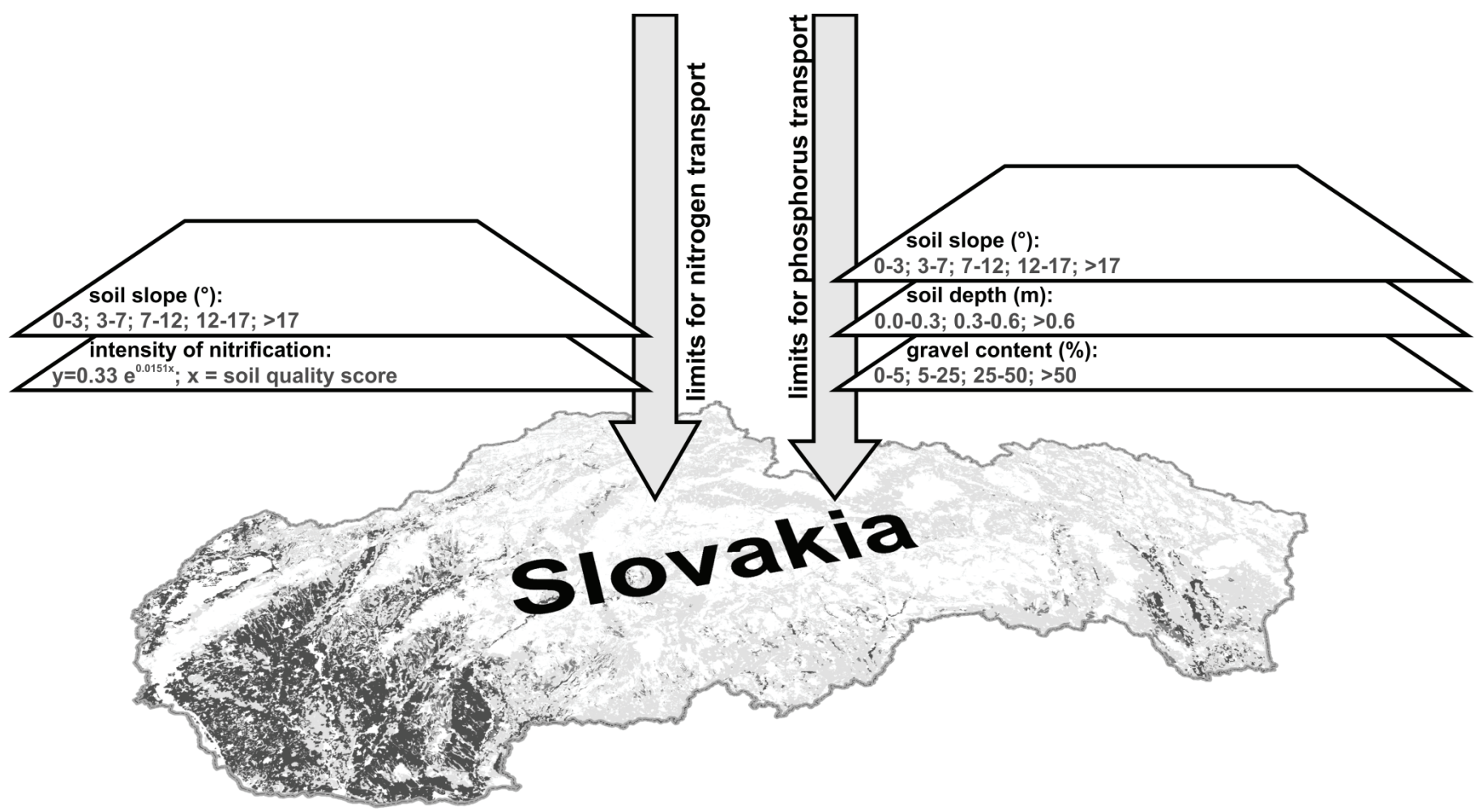

Fig. 2. Soil and locality parameters taken into account for evaluation of soil nitrogen and phosphorus transport

sons for a increase in water source nitrogen and phosphorus content.

As mentioned above, both the high nitrate nitrogen soil content and terrain slope are important factors for soil nitrogen loss. Losses through water erosion do not normally account for a large portion of the soil nitrogen budget but should be considered for surface water quality issues. The mutual combination of above mentioned soil nitrogen transport limits (Fig. 2) and the assigned coefficients (Table 2) were chosen to obtain soil nitrogen transport coefficients. These coefficients result in five categories of soil nitrogen transport intensity:

very low soil nitrogen transport - coefficient below 0.10;

low soil nitrogen transport - coefficient $0.10-0.25$;

moderate soil nitrogen transport - coefficient 0.26-0.40;

strong soil nitrogen transport - coefficient 0.41-0.50;

very strong soil nitrogen transport - coefficient over 0.50 .

The same method was chosen for phosphorus transport with soil depth, soil gravel content and location slope parameters taken into account. The mutual combination of mentioned limits (Fig. 2) and the assigned coefficients (Table 2) result in final coefficients for soil phosphorus transport. According to these coefficients, there were five categories of soil phosphorus transport intensity:

very low soil phosphorus transport - coefficient over 3.80;

low soil phosphorus transport - coefficient 2.41-3.80;

moderate soil phosphorus transport - coefficient 1.31-2.40; strong soil phosphorus transport- coefficient 0.51-1.30; very strong soil phosphorus transport - coefficient below 0.50 .
Soil categorisation from the point of view of water source pollution in the framework of chosen regions in the Slovak Republic

The observed regions were selected for their specific soil and climate parameters to show how possible nitrogen and phosphorus water pollution depends on soil quality and parameter and location slope.

The Žitný ostrov region is characterised by very fertile soils, e.g. Chernozems and Mollic Fluvisols (deep soils without gravel and with high content of humus), which are located in a very warm lowland region with low precipitation (Škvarenina et al., 2009; Vido et al., 2016). The mean soil point value is 85.7 on a 100-points scale. Mean nitrified nitrogen is $1.20 \mathrm{mg} \mathrm{N}-\mathrm{NO}_{3}{ }^{-\mathrm{kg}^{-1}}$ of soil per 14 days (e.g., more than $80 \mathrm{~kg}$ $\mathrm{N}-\mathrm{NO}_{3}{ }^{-} \mathrm{ha}^{-1}$ during the vegetation period) in these conditions, which can be defined as extreme nitrification intensity (Bielek, 1988). Therefore, the danger of nitrogen leaching from the soil in this region is very high, although the region is flat and water erosion is negligible.

Almost $90 \%$ of all agricultural soils in this region are categorised as strong and very strong nitrogen transportation (Table 3, Fig. 3), and strong nitrogen transport alone may cause strong groundwater source pollution. This can be very dangerous in this region because it is the location of major drinking water sources.

In the soil, however, phosphorus (P) is, contrary to the rather mobile nitrate $\left(\mathrm{NO}_{3}^{-}\right)$, quite immobile and vertical movement of phosphorus is assumed to be strongly restricted because of the high phosphorus fixation capacity in mineral soils (Heckrath 
Table 3

The share of individual soil categories with various intensity of soil nitrogen and phosphorus transport in the framework of the observed regions (\%)

\begin{tabular}{|c|c|c|c|c|c|}
\hline \multicolumn{6}{|c|}{ Intensity of soil nitrogen and phosphorus transport } \\
\hline \multicolumn{6}{|c|}{ Žitný ostrov } \\
\hline & very weak & weak & moderate & strong & very strong \\
\hline Nitrogen & 0.0 & 8.1 & 4.3 & 32.4 & 55.2 \\
\hline Phosphorus & 93.3 & 0.5 & 6.2 & 0.0 & 0.0 \\
\hline \multicolumn{6}{|c|}{ South Slovakian basins } \\
\hline & very weak & weak & moderate & strong & very strong \\
\hline Nitrogen & 0.8 & 9.9 & 50.1 & 38.4 & 0.8 \\
\hline Phosphorus & 74.3 & 15.5 & 1.3 & 7.4 & 1.5 \\
\hline \multicolumn{6}{|c|}{ Ondavská vrchovina } \\
\hline & very weak & weak & moderate & strong & very strong \\
\hline Nitrogen & 38.0 & 38.8 & 21.1 & 2.1 & 0.0 \\
\hline Phosphorus & 18.4 & 15.4 & 18.0 & 29.6 & 18.6 \\
\hline
\end{tabular}

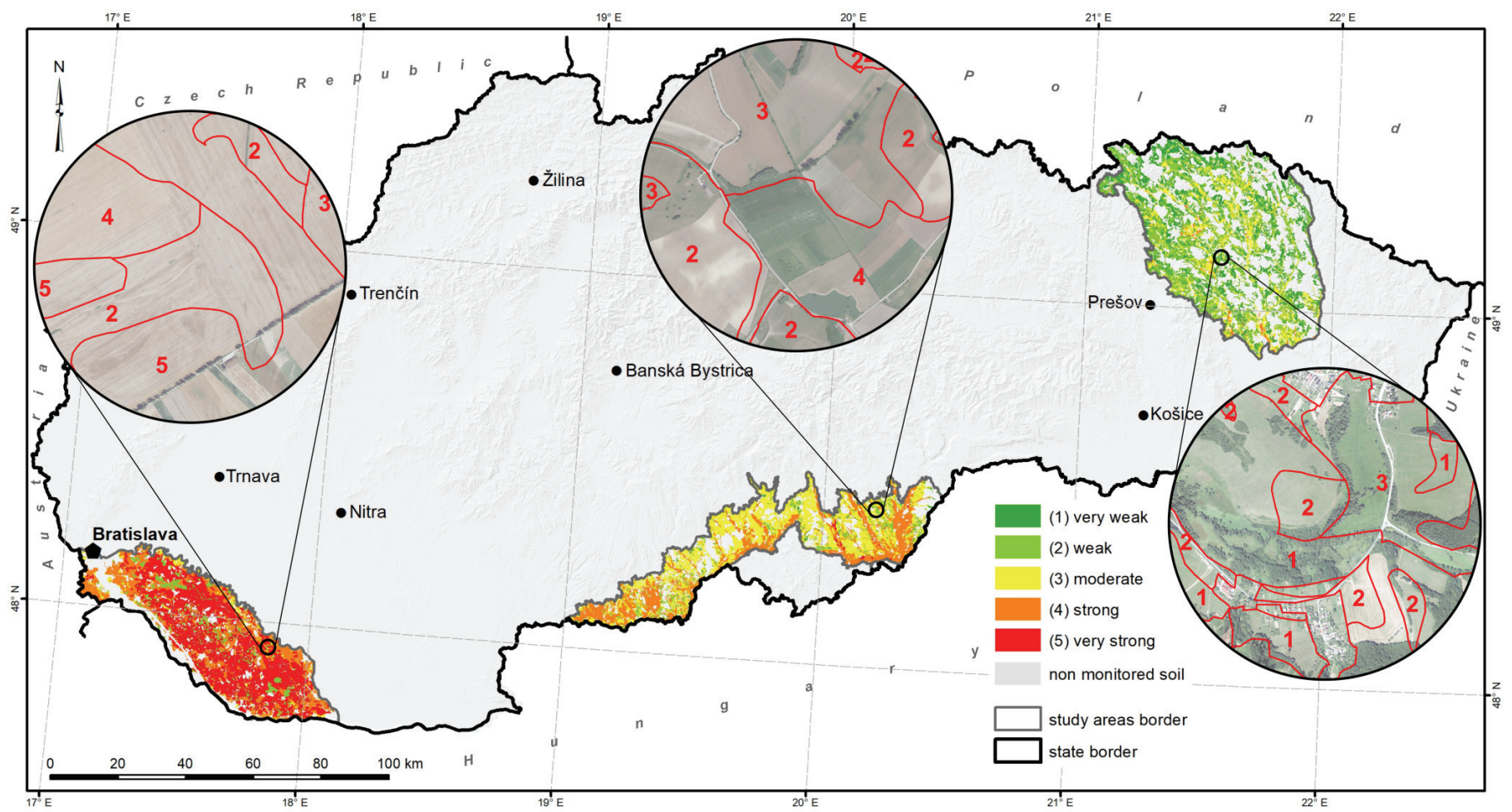

Fig. 3. The soil categories of observed regions from the point of view of soil nitrogen transport and detailed view over several hundred hectares

et al. 1995; Sims et al., 1998). However, the high positive soil phosphorus balance following high fertilization suggests a bigP surplus, and constitutes a potential threat to the quality of groundwater and surface waters (Gaj et al., 2018). Although recent research has revealed that phosphorus leaching can occur from heavily fertilised agricultural lands (McDowell and Sharpley, 2004), soluble $\mathrm{P}$ losses of $<1 \mathrm{~kg} \mathrm{P} \mathrm{ha}^{-1} \mathrm{yr}^{-1}$ are more common on the whole (Sims et al., 1998). Phosphorus transport along the soil profile is very weak in this region due to the deep soils in which high phosphorus attachment to the soil particles and/or on organic matter can occur. The absence of water erosion helps to keep the phosphorus in the soil. On the other hand, soils in the mentioned region are calcareous, which helps to keep the phosphorus in place. Calcium phosphates made up around onethird of the total phosphorus content in the upper soil. With the slightly alkaline $\mathrm{pH}$ of the manured soil, calcium phosphates are not readily dissolved, and will not contribute to phosphorus leaching hence excess phosphorus retained in the form of cal- 
cium phosphates in the heavily manured soils can be considered as a rather stable form (Schmieder, 2019).

More than $93 \%$ of the total area of agricultural soils is characterized by very weak phosphorus soil transport (Table 3, Fig. 4).

The South Slovakian basins region is located in the southern part of middle Slovakia. Middle fertile soils (mainly Haplic Luvisols and Dystric Planosols) are common there. When compared with the soils in Žitný ostrov, the soils are not so deep (the bedrock is located closer to the surface) and have a steeper slope. The mean point value reaches 62.9 on a 100-point scale. Mean nitrified nitrogen is $0.85 \mathrm{mg} \mathrm{N}-\mathrm{NO}_{3}{ }^{-} \mathrm{kg}^{-1}$ of soil per 14 days (e.g. about $60 \mathrm{~kg} \mathrm{~N}-\mathrm{NO}_{3}^{-} \mathrm{ha}^{-1}$ during the vegetation period). This intensity of nitrification is defined as high (Bielek, 1998). All above mentioned facts result in a less intensive soil nitrogen transport (Table 3, Fig. 3). A half of the agricultural soils are moderate nitrogen transport, which means that possible water source pollution is moderate. However, soil management can significantly influence the soil nitrogen loss. Bramorski et al. (2015) reported that the absence of soil tillage led to higher soil erosion and higher total nitrogen losses mainly in organic form and associated with the finer soil minerals. On the other hand, the losses of fertiliser-derived $\mathrm{N}$ from tilled soil plots were higher.

The danger of stronger soil phosphorus transport increases in the South Slovakian region, especially due to greater location slope, where water erosion has more favourable conditions to develop. Another reason for phosphorus leaching is differing soil textures. This risk is mainly attributed to structured soils like clay and clay loams, where macropores may provide rapid transport of solutes and particles (Jarvis, 2007). On the other hand, for coarse-textured soils without macropores, the direct risk of $\mathrm{P}$ leaching losses after $\mathrm{P}$ application is generally low due to P adsorption (van Es et al., 2004; Glæsner et al., 2011; Sørensen and Rubæk, 2012).

More than $10 \%$ of total area of agricultural soils in this region are in the moderate, strong and very strong soil phosphorus transportation categories (Table 3, Fig. 4), which is in part due to the different soil textures compared with the above mentioned Žitný ostrov region.

The region Ondavská vrchovina (a cold region with low soil quality) is located in north-eastern Slovakia. The terrain is relatively hilly and the most widespread soil types are Cambisols with a relatively high gravel content as well as Gleyic Fluvisols with a high clay content in the southern part of this region. These soils are the least fertile of all the observed regions. The mean point value reaches only 38.9 on a 100-point scale and only 0.59

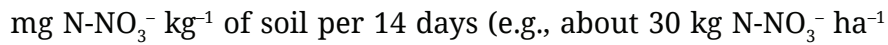
during the vegetation period) is nitrified in these conditions. This is called low nitrification intensity (Bielek, 1998).

Because most soils are located on relatively steep slopes, it can be assumed that nutrient transport should be strong. This was not confirmed in the case of nitrogen due to the very small amount of nitrified nitrogen. Of the total area of agricultural soils, three-quarters are categorised weak and very weak nitrogen transportation. Low intensity of nitrification alone limits the strong nitrogen soil transport (Table 3, Fig. 3).

As mentioned above, the soils are not very deep, and contain a high amount of gravel. In combination with the hilly feature of the country, phosphorus transport is strong. The concentrations of eroded phosphorus in water are strongly influenced by the applied soil management system and increase with the intensity of fertilisation and soil tillage (Bertol et al., 2003). Szara

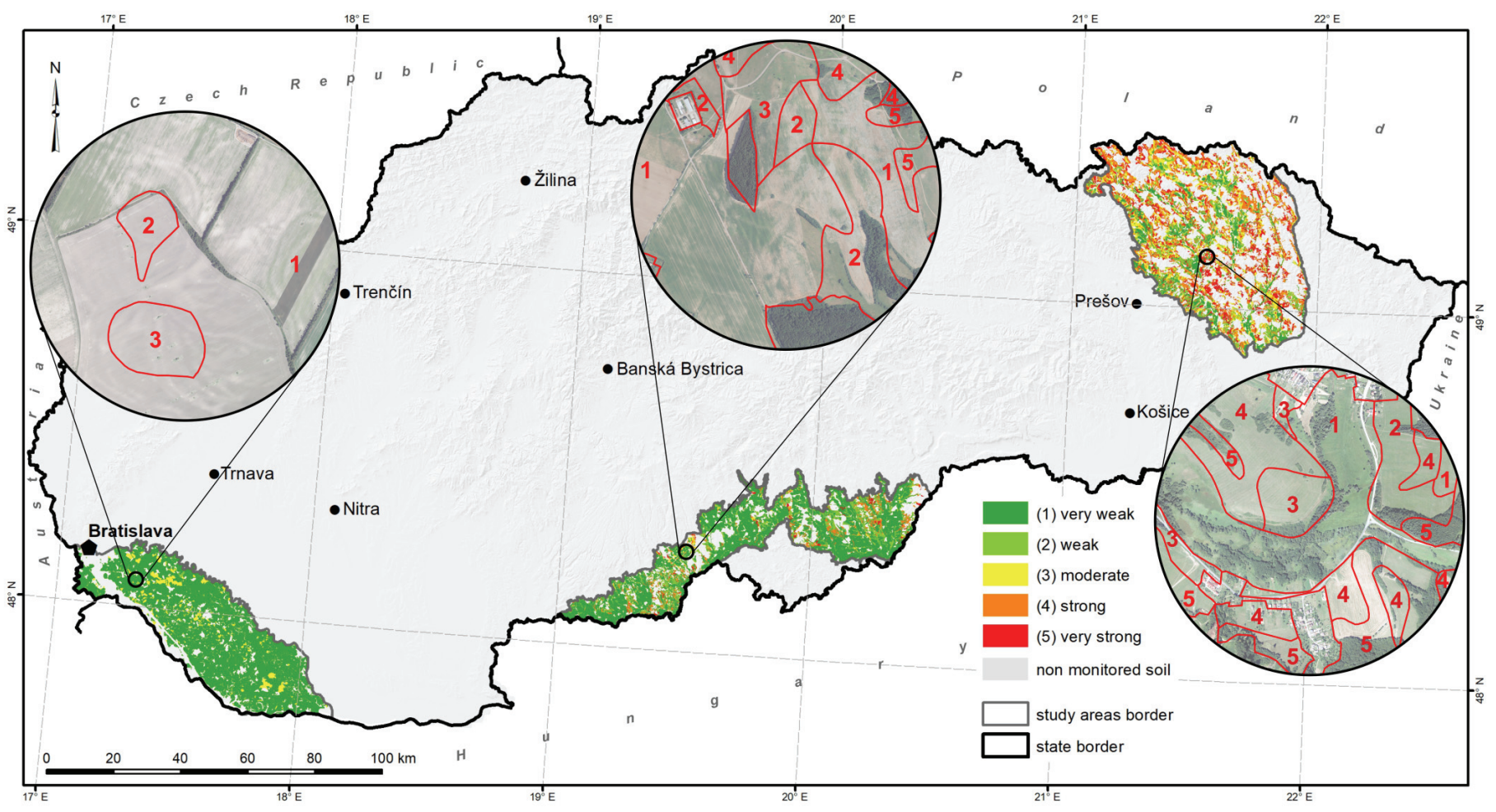

Fig. 4. The soil categories of observed regions from the point of view of soil phosphorus transport and detailed view over several hundred hectares 
et al. (2019) reported that liming applied in combination with mineral fertilisers reduces sandy soil sorption capacity leading to higher soil profile phosphorus mobility, causing phosphorus release from the soil. Farias et al. (2018) found that the highest losses of phosphorus occur on slopes with concave land forms, reaching values higher than $0.02 \mathrm{mg} \mathrm{l}^{-1}$, which is a critical value for eutrophication.

This region is characterised by its hilly landscape, and almost one-half of the agricultural soils are in the strong and very strong phosphorus transport categories. Therefore the risk of water source phosphorus pollution is relatively high (Table 3, Fig. 4). Increased amounts of phosphorus in water can be detected in all these places.

\section{Conclusions}

Generally, the potential nutrient (nitrogen and phosphorus) pollution of water sources is related to intensive and/or poor agricultural practices. Soil transport properties provide information about vertical and horizontal nutrient transport. This leads to eutrophication, as the surplus of soil pollutants can enter water sources.

The above mentioned algorithm can, on the basis of known parameters, classify each soil location based on potential watersource pollution category.

Very weak, weak and moderate nitrogen transport (e.g., very weak, weak and moderate potential for water source pollution with nitrogen) was detected in almost $90 \%$ of agricultural soils in Slovakia, and only $11.4 \%$ were in the strong and very strong nitrogen transport soil categories. In the case of phosphorus, more than half of agricultural soils are in the very weak transport category. On the other hand, strong and very strong phosphorus transport occurs in more than a quarter of agricultural soils in Slovakia. Especially in the hilly landscape locations with shallow soils and/or with high gravel content, there can be an increased phosphorus content entering the water bodies and therefore there may be a decrease in water quality.

\section{Acknowledgments}

This work was supported by the Slovak Research and Development Agency under Grant No. APVV-15-0406 and Scientific Grant Agency of Ministry of Education of Slovak Republic under Grant No. VEGA 1/0059/19.

\section{References}

Addiscott, T.M., 1996. Fertilizers and nitrate leaching. [In:] Hester, R.E., Harrison, R.M. (Eds.), Agricultural Chemicals and the Environment Issues; CABI: Oxfordshire, UK. p. 1-26.

Behera, S., Madan, K. Jha, Kar, S. 2003. Dynamics of water flow and fertilizer solute leaching in lateritic soils of Kharagpur region, India. Agricultural Water Management 63, 77-98. https://doi.org/10.1016/S03783774(03)00175-6

Bertol, I., Mello, E.L., Guadagnin, J.C., Zaparolli, A.L.V., Carrafa, M.R. 2003. Nutrient losses by water erosion. Scientia Agricola 60(3), 581-586. https://doi.org/10.1590/S0103-90162003000300025
Bielek, P. 1998. Nitrogen in agricultural soils. VÚPU Bratislava. Bratislava, Slovakia, 256 pp., ISBN 80-85361-44-2. (in Slovak with abstract in English).

Billen, G., Garnier, J. 1999. Nitrogen transfers through the Seine drainage network: a budget based on the application of the Riverstrahler model. Hydrobiologia 410, 139-150. https://doi.org/10.1023/ A:1003838116725

Birgand, F., Skaggs, R.W., Cheischer, G.M., Gillliam, J.W. 2007. Nitrogen removal in streams of agricultural catchments - a literature review. Critical Review in Environmental Science and Technology 37, 381-487. https://doi.org/10.1080/10643380600966426

Bramorski, J., Trivelin, P.C.O., Crestana, S. 2015. Nitrogen loss by erosion from mechanically tilled and untilled soil under successive simulated rainfalls. Revista Brasileira de Ciencia do Solo 39(4), 1204-1211. https://doi.org/10.1590/01000683rbcs20140521

Carpenter, S.R., Faraco, N.F., Correl, D.L., Howarth, R.W., Sharpley, A.N., Smith, V.H. 1998. Nonpoint pollution of surface waters with phosphorus and nitrogen. Ecological Application 3, 559-568. https://doi. org/10.1890/1051-0761(1998)008[0559:NPOSWW]2.0.CO;2

Di, H.J., Cameron, K.C. 2002. Nitrate leaching in temperate agroecosystems: Sources, factors and mitigating strategies. Nutrient Cyclingin Agroecosystems 64, 237-256, https://doi.org/10.1023/A:1021471531188

Džatko, M. 2002. The evaluation of productive potential of agricultural soils and soil-ecological regions in Slovakia. VÚPOP Bratislava, Bratislava. 88 p. ISBN 80-85361-94-9 (in Slovak).

Engström, L., Stenberg, M., Aronsson, H., Lindén, B. 2010. Reducing nitrate leaching after winter oilseed rape and peas in mild and cold winters. Agronomy for Sustainable Development 31, 337-347. https://doi.org/10.1051/agro/2010035

van Es, H.M., Schnindelbeck, R.R., Jokela, W.E. 2004. Effect of manure application timing, crop and soil type on phosphorus leaching. Journal of Environmental Quality 33, 1070-1080.

Farias, V.L.S., Filho, M.V.M., de Paula, D.T., Siqueira, D.S. 2018. Modeling of phosphorus losses by water erosion. Engenharia Agricola, Jaboticabal 38(1), 14-157. https://dx.doi.org/10.1590/1809-4430-Eng.Agric. v38n1p149-157/2018

Fazekašová, D., Boguská, Z., Fazekaš, J., Škvareninová, J., Chovancová, J. 2016. Contamination of vegetation growing on soils and substrates in the unhygienic region of Central Spis (Slovakia) polluted by heavy metals. Journal of Environmental Biology 37(6), 1335-1340. ISSN 0254-8704

Gaj, R., Budka, A., Antonkiewicz, J., Bak, K., Izychard, P. Effect of long-term slurry application on contents of available forms of soil macronutrients. Soil Science Annual 2018, 69(3): 194-204. https://doi.org/10.2478/ ssa-2018-0020

Garnier, M., Recanatesi, F., Ripa, M.N., Leone, A. 2010. Agricultural nitrate monitoring in a lake basin in central Italy: A further step ahead towards an integrated nutrient management aimed at controlling water pollution. Environmental Monitoring and Assessment 170, 273-286. https://doi.org/10.1007/s10661-009-1231-z

Glæsner, N., Kjaergaard, C., Rubæk, G.H., Magid, J. 2011. Interactions between soil texture and placement of dairy slurry application: II, Leaching of phosphorus forms. Journal of Environmental Quality 40, 344-351. https://doi.org/10.2134/jeq2010.0318

Goulding, K. 2000. Nitrate leaching from arable and horticultural land. Soil Use Management 16, 145-151. https://doi.org/10.1111/j.14752743.2000.tb00218.x

Gömöryová, E., Stř̌elcová, K., Škvarenina, J., Gömöry, D. 2013. Responses of soil microorganisms and water content in forest floor horizons to environmental factors. European Journal of Soil Biology 55, 71-76. https://doi.org/10.1016/j.ejsobi.2012.12.001

Heckrath, N., Brookes, P.C., Poulton, P.R., Goulding, K.W.T. 1995. Phosphorous leaching from soils containing different phosphorous concentrations in the Broadbalk experiment. Journal of Environmental Quality 24, 904-910. https://doi.org/10.2134/jeq1995.00472425002400050018x 
Horel, A., Lichner, L., Alaoui, A., Czachor, H., Nagy, V., Tóth, E. 2014. Transport of iodide in structured clay-loam soil under maize during irrigation experiments analyzed using HYDRUS model. Biologia 69(11), 1531-1538. https://doi.org/10.2478/s11756-014-0465-6

Hou, P., Gao, Q., Xie, R., Li, S., Meng, Q., Kirkby, E.A., Römheld, V., Müller, T., Zhang, F., Cui, Z., Chen, X. 2012. Grain yields in relation to n requirement: Optimizing nitrogen management for spring maize grown in China. Field Crops Research 129, 1-6. https://doi.org/10.1016/j.fcr.2012.01.006

Jarvis, N.J. 2007. A review of non-equilibrium water flow and solute transport in soil macropores: principles, controlling factors and consequences for water quality. European Journal of Soil Science 58, 523-546. https://doi.org/10.1111/j.1365-2389.2007.00915.x

Ju, X.T., Kou, C.L., Zhang, F.S., Christie, P. 2006. Nitrogen balance and groundwater nitrate contamination: Comparison among three intensive cropping systems on the North China Plain. Environmental Pollution 143(1), 117-125. https://doi.org/10.1016/j.envpol.2005.11.005

Ju, X.T., Xing, G.X., Chen, X.P., Zhang, S.L., Zhang, L.J., Liu, X.J., Cui, Z.L., Yin, B., Christie, P., Zhu, Z.L. Zhang, F.S. 2009. Reducing environmental risk by improving in management in intensive Chinese agricultural systems. Proceedings of the National Academy of Science of the USA 106(9), 3041-3046. https://doi.org/10.1073/pnas.0813417106

Koco, Š., Skalský, R., Barančíková, G., Tarasovičová, Z., Makovníková, J., Gutteková, M., Koleda, P. 2016. Effect of soil management in agricultural land for the development of soil organic carbon stocks. Folia Geographica 58(1), 22-33.

Kumazawa, K. 2002. Nitrogen fertilization and nitrate pollution in groundwater in Japan: Present status and measures for sustainable agriculture. Nutrient Cycling in Agroecosystems 63(2-3), 129-137. https://doi.org/10.1023/A:1021198721003

McDowell, R.W., Sharpley, A.N. 2004. Variation of phosphorus leached from Pennsylvanian soils amended with manures, composts or inorganic fertilizer. Agriculture, Ecosystems and Environment 102, 17-27. https://doi.org/10.1016/j.agee.2003.07.002

Mekonnen, M.M., Lutter, S., Martinez, A. 2016. Anthropogenic nitrogen and phosphorus emissions and related grey water footprints caused by EU-27's crop production and consumption. Water 8(1), 30. https:// doi.org/10.3390/w8010030

Mind'aš, J., Škvarenina, J. 1995. Chemical composition of fog cloud and rain snow water in Biosphere Reserve Pol'ana. Ekologia-Bratislava 14, 125-137.

Nolan, B.T. 2001. Relating nitrogen sources and aquifer susceptibility to nitrate in shallow groundwaters of the United States, Groundwater 39, 290-299. https://doi.org/10.1111/j.1745-6584.2001.tb02311.x

Oenema, O., Bleeker, A., Braathen, N.A., Budnakova, M., Bull, K., Cermak, P., Geupel, M., Hicks, K., Hoft, R. Kozlova, N. 2011. Nitrogen in current European policies. [In:] Sutton, M., Howard, C., Erisman, J., Billen, G., Bleeker, A., Grennfelt, P., Grinsven, H., Grizzetti, B. (Eds.), The European Nitrogen Assessment; Cambridge University Press: Cambridge, UK, 62-81. ISBN 978-1107006126.

Puckett, L.J., Tesoriero, A.J., Dubrovsky, N.M. 2011. Nitrogen contamination of surficial aquifers-a growing legacy. Environmental Science and Technology 45, 839-844. https://doi.org/10.1021/es1038358

Rivett, M.O., Buss, S.R., Morgan, P., Smith, J.W.N., Bemment, C.D. 2008. Nitrate attenuation in groundwater: a review of biogeochemical controlling processes. Water Research 42, 215-232. https://doi. org/10.1016/j.watres.2008.07.020

Schmieder, F. 2019. Phosphorus speciation in Swedish arable soils with high leaching potential. Doctoral thesis. Acta Universitatis Agriculturae Sueciae 83.100 p. https://pub.epsilon.slu.se/16456/7/schmieder_f_ 191120.pdf

Shen, Z., Chen, L., Qian, H., Qiu, J., Xie, H., Liu, R. 2013. Assessment of nitrogen and phosphorus loads and causal factors from different land use and soil types in the Three Gorges Reservoir area. Science of the Total Environment 454-455, 383-392, https://doi.org/10.1016/ j.scitotenv.2013.03.036
Sims, J.T., Simard, R.R., Joern, B.C. 1998. Phosphorus loss in agricultural drainage: historical perspective and current research. Journal of Environmental Quality 29, 111-116. https://doi.org/10.2134/jeq1998.004 $72425002700020006 x$

Sørensen, P., Rubæk, G.H. 2012. Leaching of nitrate and phosphorus after autumn and spring application of separated animal manures to winter wheat. Soil Use and Management 28, 1-11. https://doi.org/10.1111/ j.1475-2743.2011.00382.x

Sui, J., Wang, J., Gong, S., Xu, D., Zhang, Y. 2015. Effect of nitrogen and irrigation application on water movement and nitrogen transport for a wheat crop under drip irrigation in the North China Plain. Water 7(11), 6651-6672. https://doi.org/10.3390/w7116651

Szara, E., Sosulski, T., Szymanska, M.: Impact of long-term liming on sandy soil phosphorus sorption properties. Soil Science Annual 2019 70(1): 13-20. https://doi.org/10.2478/ssa-2019-0002

Škvarenina, J., Tomlain, J., Hrvol', J., Škvareninová, J. 2009. Occurrence of Dry and Wet Periods in Altitudinal Vegetation Stages of West Carpathians in Slovakia: Time-Series Analysis 1951-2005. [In:] Střelcová et al. (Eds.): Bioclimatology and Natural Hazards, Springer Netherlands. p. 97-106.

Tang, Z., Qiu, J.J., Zhou, G.Y., Wang, L.G. 2010. Effects of different water and organic fertilizer managements on the $\mathrm{N}$ balance and nitrate leaching in sunlight greenhouse vegetable system. Soil and Fertilizer Sciences in China 1, 19-24.

Timsina, J., Singh, U., Badaruddin, M., Meisner, C., Amin, M.R. 2001. Cultivar, nitrogen, and water effects on productivity, and nitrogen-use efficiency and balance for rice-wheat sequences of Bangladesh. Field Crops Research 72(2), 143-161. https://doi.org/10.1016/S03784290(01)00171-X

Torma, S. 2003. The categorization of soil accumulates function concerning nutrients. Phytopedon (Bratislava) 2, 92-96.

Torma, S., Barančíková, G., Makovníková, J., Koco, Š., Fazekašová, D. 2013. The possible water pollution from agricultural soils. In: Conference proceedings from 13th International multidisciplinary scientific conference SGEM 2013 „Water resources, forest, marine and ocean ecosystems“. June 16-22, 2013, Albena, Bulgaria, ISBN 978-619-7105-02-5, p. 725-732.

Torma, S., Vilček, J. 2015. Soil transport function and its use in environment protection. In: 7th Congress of the European Society for Soil Conservation "Agroecological assessment and functional-environmental optimization of soils and terrestrial ecosystems”. Moscow, Russia, May 18-22, 2015, p. 82-85, ISBN 978-5-9906787-0-5.

Vido, J., Střelcová, K., Nalevanková, P., Leštianska, A., Kandrík, R., Pástorová, A., Škvarenina, J., Tadesse, T. 2016. Identifying the relationships of climate and physiological responses of a beech forest using the Standardised Precipitation Index: a case study for Slovakia. Journal of Hydrology and Hydromechanics 64(3), 246-251. https:// doi.org/10.1515/johh-2016-0019

Xu, L., Niu, H., Xu, J., Wang, X. 2013. Nitrate-Nitrogen Leaching and Modeling in Intensive Agriculture Farmland in China. The Scientific World Journal. Article ID 353086. https://doi.org/10.1155/2013/353086

Zhang, Y.M., Hu, C.S., Zhang, J.B., Chen, D.L., Li, X.X. 2005. Nitrate leaching in an irrigated wheat-maize rotation field in the north China plain. Pedosphere 15, 196-203.

Zhu, J.H., Li, X.L., Christie, P., Li, J.L. 2005. Environmental implications of low nitrogen use efficiency in excessively fertilized hot pepper (Capsicum frutescens L.) cropping systems. Agriculture, Ecosystems and Environment 111, 70-80. https://doi.org/10.1016/ j.agee.2005.04.025 